\author{
Vice Šunjić \\ Sveučilište u Zadru \\ Obala kralja Petra Krešimira IV/2, HR-23000 Zadar \\ vsunjic@unizd.hr
}

\title{
PROMIŠLJANJA O PRAVOPISU U HRVATSKOJ PORATNOJ EMIGRACIJI
}

U ovome će radu biti riječi o pogledima predstavnika hrvatske poratne emigracije na dvije pravopisne koncepcije koje su se izmjenjivale u hrvatskoj pravopisnoj praksi. Uz nekolicinu onih koji su zagovarali povratak morfonološkoj, korijenskoj ili etimološkoj pravopisnoj koncepciji pišući svoja jezikoslovna i književna djela po pravilima morfonološkoga/ korijenskoga pisanja postojala je i velika većina koja je ustrajala na upotrebi pravopisa zasnovana pretežito na fonološkome načelu. Za njih je pitanje povratka morfonološkome/ korijenskome pravopisu značilo oživljavanje jedne prekinute pravopisne tradicije kojom bi se zanemarila i obezvrijedila sva dostignuća u razvoju hrvatskoga književnog jezika između dvaju svjetskih ratova.

\section{Uvodno}

Od sedamdesetih i osamdesetih godina 19. stoljeća u jezikoslovnoj se kroatistici jasno ocrtavaju i izmjenjuju dvije pravopisne koncepcije. U prošlosti, a nerijetko i danas, koncepcije se različito, ali i neprecizno nazivaju. Jedna je poznata kao etimološka, korijenska, tvorbena ili morfonološka, dok se za drugu rabe nazivi poput fonološka, zvučna ili fonetska. ${ }^{1}$ Da bismo lakše razumjeli oprečne stavove predstavnika hrvatske poratne emigracije o tome koja je pravopisna koncepcija trebala imati primat $u$ hrvatskoj ortografskoj praksi druge polovice dvadesetoga stoljeća, kratko ćemo se prisjetiti nekih prošlostoljetnih pravopisnih kretanja.

U radu će se upotrebljavati termin (izraziti) morfonološki kao zamjena za etimološki, korijenski i tvorbeni, dok će fonološko-morfonološki biti zamjena za fonološki i fonetski pravopis. 
Pravopisna se tematika u preporodnome vremenu nametnula kao važno pitanje u hrvatskoj filologiji. Poznato je kako je cjelokupan kulturni, ali i politički program hrvatskoga narodnog preporoda počivao na jezičnome i pravopisnome ujedinjenju svih hrvatskih krajeva. Ilirci su smatrali kako će samo zajedničkim slovopisom (grafijom), književnim jezikom i pravopisom (ortografijom) ostvariti hrvatsko nacionalno jedinstvo. Stoga se kod hrvatskih jezikoslovaca uvriježilo mišljenje kako se baš u vrijeme hrvatskoga narodnog preporoda uz uređenje latiničnoga slovopisa (grafije) za potrebe ,ilirskoga jezika” [hrvatskoga književnog jezika (novo)štokavske osnovice] po češkome uzoru uveo i snažno zagovarao u osnovi i etimološki (etimologijski, korijenski) pravopis² ${ }^{2}$ Samardžija 2014, Vince 1978, Jonke 1971). Samardžija smatra kako je već 1850. godine Pravopis ilirskoga jezika Josipa Partaša bio ,prvi hrvatski pravopisni priručnik hrvatskoga u današnjem značenju naziva pravopis" (Samardžija 2014: 81) sastavljen po pravilima morfonološkoga pisanja. U jednoj od Partaševih kritičkih bilježaka u kojoj se osvrće na loše strane fonološkoga (,glasiteljnog”) pravopisa Samardžija prepoznaje da su već tada postojali zagovornici fonoloških pravopisnih načela. Stoga možemo reći kako u drugoj polovici 19. stoljeća na jednoj strani imamo predstavnike zagrebačke filološke škole koji su ustrajno zagovarali zadržavanje „etimologičnosti i neke tradicionalnosti starijega pravopisa” (Vince 1978: 230), dok su mladi filolozi predvođeni Vatroslavom Jagićem ${ }^{3}$ uz podršku prvoga tajnika Jugoslavenske akademije znanosti i umjetnosti Đure Daničića bili zagovornici uvođenja „zvučnoga”, tj. fonološki koncipirana pravopisa.

U osamdesetim godinama 19. stoljeća pitanje pravopisnih koncepcija u jezikoslovnoj kroatistici prestaje biti samo filološko te postaje i političko pitanje. Kada na vlast 1883. godine dolaze unionisti (mađaroni) predvođeni hrvatskoslavonskim banom K. Khuenom-Héderváryjem, dolazi do „pravopisnog obrata" u korist fonološkoga (,fonetičkoga”) hrvatskog pravopisa. Pobornici ideje o fonološki koncipiranome pravopisu pozvali su se tada na neke filološke zamisli

\footnotetext{
Ovdje vrijedi spomenuti kako su i u dopreporodnome razdoblju u nestalnome omjeru bile zastupljene obje pravopisne koncepcije, odnosno, kako navodi Brozović, „vladao je jedan nedovoljno stabilan kompromis između fonološkoga i morfonološkoga pravopisnog principa, s tendencijom k jačanju fonološkoga" (Brozović 1985: 5 navedeno prema Badurina 2017: 94).

3 Vatroslav je Jagić u početku i sam bio pristaša zagrebačke filološke škole, a potom je u članku Naš pravopis 1864. godine iznio argumente protiv uvođenja izrazitoga etimološkog pravopisa (čiji je vatreni zagovaratelj bio predvodnik škole Adolfo Veber Tkalčević) te se tako svrstao na stranu pobornika fonološkoga pravopisa (usp. Badurina 2017: 103-104, Samardžija 2014: 83).
} 
Vuka Stefanovića Karadžića ${ }^{4}$ i Đure Daničića, pa se tako stvorilo uvjerenje da je „fonološki pravopis srpski, a morfonološki hrvatski” (Samardžija 1993: 11). Ta će pravopisna distinkcija u vremenu izražene jezične unifikacije hrvatskoga i srpskoga književnog jezika u drugoj polovici dvadesetoga stoljeća obilježiti gotovo sva nova izdanja hrvatskih ortografskih priručnika. Podjela pravopisnih koncepcija po nacionalnome ključu poslužit će kao glavni argument nekim predstavnicima hrvatske poratne emigracije koji će se u svojim radovima zalagati za rehabilitaciju „tradicionalnoga hrvatskog etimološkog/korijenskog pravopisa”. Tiskanjem Hrvatskoga pravopisa Ivana Broza 1892. godine kao prvoga službenog fonološki koncipirana ortografskog priručnika hrvatskoga jezika otpočelo je novo poglavlje hrvatske (pravo)pismenosti koje će se nastaviti tijekom cijele prve polovice dvadesetoga stoljeća u pravopisnim priručnicima Dragutina Boranića. Fonološka tradicija Broz-Boranićeva hrvatskoga pravopisa bit će privremeno prekinuta uspostavom Nezavisne Države Hrvatske: prvo pokušajem ,umjerenoga povećanja etimoloških elemenata u fonološkoj koncepciji hrvatskoga pravopisa" (Samardžija 2005: 18) neobjavljenim Hrvatskim pravopisom F. Cipre, P. Guberine i K. Krstića 1941. godine ${ }^{5}$, a zatim privremenim i nevelikim ortografskim priručnikom Koriensko pisanje iz 1942. u izdanju Hrvatskoga državnog ureda za jezik kao jedinoga službenog i, po prvi put u povijesti hrvatskih pravopisa, javno dopuštena priručnika. Pred sam kraj ustaške vladavine 1944. godine objavljen je Hrvatski pravopis ${ }^{6}$ čiji su urednici, uz suradnju članova Hrvatskoga državnog ureda za jezik, bili Franjo Cipra i Adolf Bratoljub Klaić. Opsežan i morfonološki koncipiran ortografski priručnik trebao je naznačiti ,,povratak hrvatskoj nasilno prekinutoj pravopisnoj tradiciji” (Samardžija 1993: 39), tvrdnji na kojoj su ustaške vlasti temeljile povratak morfonološki koncipiranomu pravopisu.

U vremenu poraća ponovno je u službenu upotrebu vraćen na fonološkim osnovama zasnovan Boranićev pravopis. Do tada već dobro stabilizirana hrvatska pravopisna norma nije bila destabilizirana ni ,zajedničkim” pravopisom hrvatskoga i srpskoga jezika koji je objavljen krajem pedesetih godina kao plod novo-

\footnotetext{
4 Badurina (2017: 105) smatra kako hrvatski vukovci nisu u potpunosti slijedili rigidni (istaknula L. B.) program V. S. Karadžića i njegovih ortodoksnih sljedbenika, već su zagovarali znatno blažu varijantu vukovstva (istaknula L. B.) kako po pitanju književnojezične koncepcije, tako i po pitanju pravopisne norme (fonološko načelo s elementima morfonološkoga). Hrvatska jezična situacija i tradicija hrvatske pismenosti bili su glavni uzroci takve umjerenosti.

5 Pravopis je objavljen (pretisnut) 1998. godine.

6 Pravopis je pretisnut 1992. godine pod naslovom Hrvatski korijenski pravopis.
} 
sadskoga sastanaka hrvatskih i srpskih jezikoslovaca. Uzimajući kao predložak deveto izdanje Boranićeva pravopisa, sastavljen je još jedan Hrvatski pravopis, onaj iz 1971. godine, koji je nakon zabrane svjetlo dana ugledao u Londonu u izdanju Nove Hrvatske, trajno priskrbivši popularan naziv „londonac”. Do početka devedesetih i proglašenja Hrvatske samostalnom i suverenom republikom objavljen je još jedan pravopisni priručnik. Godine 1986. Pravopisni priručnik hrvatskoga ili srpskoga jezika V. Anića i J. Silića samo je nastavio s hrvatskom pravopisnom praksom.

\section{Zagovaratelji morfonološkoga pravopisa}

Brojna skupina hrvatskih intelektualaca koji su uspjeli preživjeti Drugi svjetski rat i ratne strahote bila je, napustivši Hrvatsku, raspršena po raznim zemljama svijeta i nastojala se uklopiti u jezik i svakidašnjicu zemlje u kojoj su se našli, odnosno u koju su se uselili. U rijetkim glasilima na hrvatskome jeziku tih poratnih godina pisalo se uglavnom „korienski”, odnosno po pravilima izrazitijega morfonološki koncipirana pravopisa. Još uvijek je nedovoljno istražena jezična slika hrvatske tiskane emigrantske riječi tih poratnih logorskih i kasnih četrdesetih godina. Uglavnom, većina onodobnih novina i knjiga, kojima su se htjeli sačuvati duh i tradicija Nezavisne Države Hrvatske, pisani su „korienski”. Drugi su opet prihvatili i slijedili, iako ne u potpunosti, Broz-Boranićevu pravopisnu tradiciju, za koju su neki i u emigraciji tvrdili da zapravo i jest najbolje odgovarala hrvatskomu jeziku, bez obzira na to što je dobrim dijelom, po njihovu mišljenju, usvajala „vukovska načela”.

Urednici gotovo svih časopisa i novina u emigraciji koji su bili bili sljedbenici politike i vodstva Nezavisne Države Hrvatske, okupljeni većinom oko „općehrvatskoga, nadstranačkoga i demokratskoga pokreta” (Krašić 2018: 20) nazvana Hrvatski oslobodilački pokret (HOP), uređivali su i sastavljali svoje tiskovine strogo poštujući pravila izrazitoga morfonološkog pravopisa. Tako novine $\mathrm{Hr}$ vatska kao HOP-ovo stožerno glasilo u osvrtu nakon objave Deklaracije o nazivu i položaju hrvatskog književnog jezika 1967. svoje čitatelje u emigraciji, ali 
i narod u domovini ${ }^{7}$, prema ,zaključku točke 5. II. Zasjedanja Predsjedničtva HOP-a" (održana u Chicagu u rujnu 1967.) poziva na provođenje u djelo zaključka hrvatske vlade o hrvatskome jeziku i pravopisu od 14. kolovoza 1941. godine sadržana u Naredbi k zakonskoj odredbi o hrvatskom jeziku, o njegovoj čistoći i pravopisu koja je donesena 27. lipnja 1942. godine kao dodatak Zakonskoj odredbi o hrvatskom jeziku, o njegovoj čistoći i o pravopisu. ${ }^{8}$ Pitanje pravopisa bilo je strogo određeno dvama člancima, i to člankom 4., u kojemu se zahtijeva da se dugi refleks jata ,izgovara” i piše ie, te člankom 7., u kojemu stoji da se na hrvatskome jeziku ima pisati samo po „korienskom”, a ne zvučnom pravopisu. ${ }^{9}$ Ovdje vrijedi napomenuti da su pristaše HOP-a okupljene oko lista Hrvatska podržale donošenje Deklaracije o nazivu i položaju hrvatskog književnog jezika znajući da postoje razlike između njih i potpisnika upravo po pitanju upotrebe različitih pravopisa. Po istim su pravopisnim načelima sastavljani i drugi časopisi i novine HOP-ovih organizacija diljem svijeta poput Nezavisne Države Hrvatske, Hrvatske Grude, Spremnosti, Hrvatskoga putokaza, Uzdanice, ali i list Hrvatski narod kao jedino glasilo organizacije Hrvatski oslobodilački pokret (Reorganizacija) - HOP(R). ${ }^{10}$

Velik dio hrvatske poratne emigracije činili su vodstvo i članovi Hrvatske seljačke stranke. Jedan od onih koji je zagovarao promjene u hrvatskoj pravopisnoj praksi druge polovice dvadesetoga stoljeća bio je i sam predsjednik Hrvatske seljačke stranke Vladko Maček. Svojim se jezikoslovnim radom javio u poznatome emigrantskom časopisu Hrvatska revija (X/1960: 416-419) s člankom Hrvatski književni jezik i pravopis $^{11}$. Zalažući se za ponovno uvođenje „etimološkoga ili korienskoga pravopisa”, Maček naglašava kako je hrvatski književni jezik u posljednje „vrieme izkrivljen” (Maček 1960: 418) i kako se treba vratiti Antunu

\footnotetext{
Posebna napomena za narod u domovini glasi: „Narod kod kuće treba obaviestiti putem svih onih, koji dolaze u domovinu i naročito u zasebničkom dopisivanju s pojedincima, da tako dobiju točne upute, kako treba pisati pravilnim hrvatskim jezikom i pravopisom.” (Hrvatska, br. 407., studeni 1967., str. 5).

8 Više o Zakonskoj odredbi o hrvatskom jeziku, o njegovoj čistoći i pravopisu (br. CCXLIX-1083-Z.p.1941) i Provedbenoj naredbi k zakonskoj odredbi o hrvatskom jeziku, o njegovoj čistoći i o pravopisu (br. U. m. 1999-1942) vidi u Samardžija 1993: 33-20.

9 Provedbena naredba k zakonskoj odredbi o hrvatskom jeziku, njegovoj čistoći i pravopisu (Hrvatska, br. 407., studeni 1967., str. 5).

10 Više o spomenutim emigrantskim listovima u Krašić 2018: 79-116.

11 Ulomci ovoga članka objavljeni su u još jednome emigrantskom časopisu, časopisu Napridak (VII., br. 18, siječanj 1960.) uz napomenu u uvodnome dijelu kako iste stavove „Napridak zastupa i već punu godinu dana neumorno propovida".
} 
Radiću i vremenu njegova Hrvatskog doma. ${ }^{12}$ Poznato je kako su još od kraja devetnaestoga stoljeća i objave Hrvatskoga pravopisa Ivana Broza 1892. godine predstavnici Hrvatske (republikanske) seljačke stranke (H(R)SS) zajedno uz predstavnike Hrvatske stranke prava (HSP) bili gorljivi zagovornici upotrebe morfonološkoga pravopisa u hrvatskome književnom jeziku. Štoviše, razvili su posebnu inačicu pravopisa koju su upotrebljavali u svojim radovima. Posebno se izdvaja ime Rudolfa Hercega, pokretača, tajnika i glavnoga promicatelja kulturno-prosvjetnoga društva Seljačka sloga, osnovana 11. listopada 1925. godine u Zagrebu. Po svojim je jezikoslovnim stajalištima bio poznat kao gorljivi zagovornik upotrebe izrazitoga morfonološkog pravopisa.

Mačekov članak u Hrvatskoj reviji započinje uz dvije napomene uredništva: „Ovaj prilog iznimno objavljujemo u korijenskom pravopisu, jer 1. tako je pisan, i 2. pisac se u njemu zalaže za povratak na korijensko pisanje. - Ured. HR." (Maček 1960: 416). Prije negoli nešto više kažemo o Mačekovim pogledima na hrvatski književni jezik i pravopis vrijedi primijetiti kako spomenutu napomenu potpisuje uredništvo Hrvatske revije, odnosno glavni urednik Vinko Nikolić. Kao urednik najtiražnije i najpoznatije emigrantske tiskovine Nikolić nije podržavao uvođenje morfonološke pravopisne koncepcije kao osnovice pravopisa hrvatskoga književnog jezika. Svoj je časopis uređivao po pravilima fonološkoga hrvatskog pravopisa vjerujući kako tim činom svjedoči o otvorenosti i širini te kako jezik približava hrvatskim jezičnim normama koje su tada vrijedile u domovini. O Nikolićevim reakcijama na objavljivanje tekstova u emigraciji napisanim po pravilima morfonološkoga pravopisa bit će još riječi u nastavku ovoga rada.

Maček u svojemu članku hvali hrvatsku lijepu književnost staru preko petsto godina. Polazeći od Splićanina Marulića i njegove Judite, preko čakavske i kajkavske hrvatske književnosti od šesnaestoga do devetnaestoga stoljeća, dolazi do zaključka kako je hrvatski književni jezik ,ustaljen tj. dan mu je stalan oblik” (Maček 1960: 417) već 1860. godine. Tim su književnim jezikom, smatra Maček, pisali svi hrvatski književnici toga vremena predvođeni Augustom Šenoom i povjesničarom Vjekoslavom Klaićem, a važni su časopisi poput Narodnih novina, Obzora, Vijenca, Prosvjete, Doma i svijeta bili pisani istim pravopisom.

\footnotetext{
${ }_{12}$ O Antunu Radiću i hrvatskome jeziku pisao je Vinko Grubišić. Vidi: Grubišić, Vinko. 1984. Antun Radić i hrvatski jezik na prijelomu stoljeća, Hrvatski godišnjak - Hrvatski glas (ur. Mirko Meheš), Sudbury. Nav. prema pretisku Društva prijatelja Matice hrvatske, Vancouver, 1984.
} 
Isticanje pitanja pravopisa u spomenutim časopisima, ali i u samome naslovu Mačekova članka, dovoljno govori o neobjašnjivo važnome mjestu koje pravopis zauzima u jezikoslovnoj kroatistici. Maček u svojemu radu jednostavno tvrdi da je fonološki pravopis stigao u Hrvatsku s političkim promjenama 1892. godine, pa stoga dvojicu političara smatra odgovornima za nasilno uvođenje fonološkoga pravopisa u Hrvatskoj: u prvome redu bana K. Khuena-Héderváryja te njegova odjelnoga predstojnika Izidora Kršnjavoga. Eksplicitno navodi da se fonološki koncipiran pravopis pojavio u hrvatskim školama kao neka vrsta kompromisa „za volju hrvatskih Srba” (Maček 1960: 417), dok je po njegovu mišljenju jedini tradicionalni i hrvatski pravopis onaj koji je nastao na principu etimološkoga pisanja, kao i kod drugih naroda koji su svoje jezike i pravopise utemeljili isključivo na etimologiji. Oni koji to nisu učinili jesu Vuk Stefanović Karadžić i Srbi koji upotrebljavaju fonološki koncipiran pravopis te ga uz pomoć mađarona nameću Hrvatima kao jedini izbor (Maček 1960). Za Mačeka je morfonološki pravopis hrvatski, dok je fonološki pravopis srpski, ali njime u Hrvatskoj pišu i oni „koji zaziru od svega što je srpsko” (Maček 1960: 418). Njegovo poimanje fonološki koncipirana pravopisa ide toliko daleko da, navodeći primjere poput vrabca/vrapca, seljačtvo/seljaštvo, mjestni/mjesni, krstni/krsni, napominje kako on uvijek u izgovoru navedenih riječi izgovara fonem $t$, ali da taj fonem čuje i u izgovor drugih govornika hrvatskoga književnog jezika, pa čak i kod Srba koji su prešli na fonološki pravopis (Maček 1960). Maček kao da ne prepoznaje tradiciju hrvatskoga umjerenog morfonološkog pravopisa te u rješavanju pravopisnih problema strogo odjeljuje etimološke pristupe s jedne strane, a fonološke s druge. Svoj stav potkrepljuje primjerom imena vlastite domovine navodeći kako bi onda svi zagovornici fonološki koncipirana pravopisa jednostavno trebali pisati „Hrvacka, a ne Hrvatska kao što to pišu i slabije školovani hrvatski emigranti, a posebno oni iz dinarskih krajeva kod koji se još čuje i oblik Rvacka jer nisu mogli naučiti pravilno" (Maček 1960: 418).

Predsjednik HSS-a u svojemu članku upozorava na potrebu učenja standardnoga jezika zajedno s pravopisom jer se razlikuje od svakodnevnoga, pučkoga jezika i pravopisa. Uz pravopisna lutanja hrvatskih jezikoslovaca posebno se okomio na siromašenje hrvatskoga leksičkoga fonda u korist srpskoga. Tako navodi lekseme koji po njegovu mišljenju nisu dio hrvatskoga književnog jezika, već su preuzeti iz srpskoga, poput porodica umjesto obitelj, podrška umjesto podpora, sedmica umjesto tjedan, lično umjesto osobno, ručak umjesto objed, skrećući 
pozornost i na sintaktičke konstrukcije koje su strane hrvatskomu književnom jeziku, npr. Idem za Karlovac. umjesto Idem u Karlovac., Idem negdje na more. umjesto Idem nekamo na more., Idem u posjet kod rodbine. umjesto $k$ rodbini te pojašnjavajući da se „brod krca za ovo ili ono mjesto, čovjek ide u neko mjesto, a da se vozna karta kupuje za to mjesto" (Maček 1960: 419). Maček smatra kako u hrvatskome književnom jeziku samo one riječi koje su stekle gradjansko pravo mogu biti dio korpusa leksema hrvatskoga književnog jezika, bile one prevedenice, posuđenice ili usvojenice iz nekih drugih svjetskih jezika. Vjerujući kako je hrvatski književni jezik u velikoj mjeri unificiran srpskim jezikom, na kraju članka šalje poziv hrvatskim filolozima u emigraciji da vrate hrvatskomu književnom jeziku i pravopisu prijašnju čistoću kao što je hrvatsko seljaštvo sačuvalo pučki govor u dijalektima.

Među hrvatskim poratnim emigrantima bilo je pojedinaca koji su svoja književna djela sastavljali ponekad po pravilima jednoga, a ponekad po pravilima drugoga pravopisnog koncepta. Tako se npr. jedan od ponajboljih emigrantskih pjesnika Antun Bonifačić znao povremeno vraćati morfonološkomu pravopisu. Njegovo političko opredjeljenje ${ }^{13}$ također je imalo presudan utjecaj na izbor pravopisa, kao i velik broj čitatelja u emigraciji koji su samo spomenuti pravopisni koncept držali prihvatljivim. Gotovo isto bilo je s još jednim hrvatskim emigrantskim pjesnikom. Šezdesetih se godina među hrvatskim emigrantima pojavila i knjiga fra Lucijana Kordića Exodus. U izdanju Knjižnice Hrvatske revije 1964. godine u Buenos Airesu objavljeno je prvo izdanje. ${ }^{14}$ Taj ep u deset pjevanja koji kronološki prati iseljeničku tragediju hrvatskoga naroda uz antitezu čeznuća za domovinom, povratkom i slobodom jezično je zanimljiv ponajprije zbog izbora pravopisa kojim je napisan. Autor je odlučio djelo sastaviti po pravilima morfonološkoga pravopisa. Ostala svoja književna djela Kordić je pisao po pravilima fonološkoga pisanja, pa bi se moglo reći kako je korištenje morfonološkoga pravopisa u spjevu Exodus bila samo iznimka. Kako navodi Grubišić (2013), Kordić je upotrebu spomenutoga ortografskog rješenja pravdao tematikom samoga djela. Vjerovao je kako u svojemu epu, pišući o jednome „hrvatskom naraštaju pokošenih” i „dižući spomenik stratištu zvanom Bleiburg”

\footnotetext{
13 Antun je Bonifačić bio predsjednik Hrvatskoga oslobodilačkog pokreta od 1973. do 1981. godine te čelni čovjek emigrantskih listova Hrvatska i Nezavisna Država Hrvatska koji su jezično uređivani prema pravilima izrazitoga morfonološkog pravopisa iz vremena Nezavisne Države Hrvatske.

14 U NSK-u nalaze se još dva izdanja, i to drugo iz 1964. i treće iz 1965. kod istoga nakladnika.
} 
(Grubišić 2013: 48), treba upotrijebiti i pravopis toga vremena. Vrijedi primijetiti kako je Kordićevo djelo objavljeno u izdanju Knjižnice Hrvatske revije, najpoznatijega emigrantskog časopisa čiji je urednik Vinko Nikolić, koji je, kako smo već spomenuli, bio zagovornik fonološki koncipirana pravopisa vjerujući da tim izborom čuva „općehrvatsko usmjerenje” u hrvatskome književnom jeziku. Ipak, prihvatio je tiskanje Kordićeva spjeva uz napomenu na posljednjoj stranici u svim trima izdanjima: ,prema želji pisca zbirka je tiskana u korijenskom pravopisu - Uredništvo" (Kordić 1964: 127). U osvrtu' ${ }^{15}$, koji se nalazi na samim koricama Kordićeva spjeva, spominje se još jednom autorov pravopisni izbor. Kaže se da ,starohrvatski korijenski pravopis ima ovdje značenje i miris tisućugodišnjega vina u modernim hrvatskim bačvama" (Kordić 1964: 1), što nam još jednom potvrđuje razmišljanje samoga autora da je pravopisni izbor bio uvjetovan književnom tematikom samoga epa.

O drugoj godišnjici objave Deklaracije o nazivu i položaju hrvatskoga književnog jezika javio se autor spjeva Exodus u Hrvatskoj Reviji s člankom pod naslovom Drama i enigma hrvatskoga jezika. Zanimljivo je primijetiti da i u spomenutome članku na jednome mjestu Kordić aktualizira pitanje izbora službenoga pravopisa hrvatskoga književnog jezika u drugoj polovici dvadesetoga stoljeća. Autor smatra kako se hrvatski jezik mora vratiti na ,normalni kolosijek” svojega razvoja i izvući se iz „serbokroatističke abnormalne klopke” u koju je gurnut raznim političkim odlukama u Socijalističkoj Federativnoj Republici Jugoslaviji (Kordić 1969: 271). Za Kordića će autonomni i samostalni hrvatski književni jezik biti zasnovan „,na jednoj vrsti etimološkoga tj. korijenskoga pravopisa, jer on mnogo bolje odgovara geniju i stilu jezika, na «jatovsko ijekavskom» govoru koji je potvrđen u književnoj praksi i koji čuva sva tri «jatovska izgovora ije, je, e» na uvođenju suglasnika «h» na dočetku genitiva množine, da bi se istakla razlika od drugih sličnih padeža" (Kordić 1969: 271).

Najdalje je u zagovaranja uvođenja morfonološkoga pravopisa, ali i novoštokavske ikavice kao osnovice hrvatskoga književnog jezika, među predstavnicima hrvatske poratne emigracije otišao Petar Tutavac Bilić. Vjerujući da su jedino novoštokavska ikavica i etimološki/korijenski pravopis ono na čemu mora biti izgrađen hrvatski književni/standardni jezik, ne pristajući ni na kakve jezično15 Osvrt na koricama knjige nepotpisan je, ali je jasno navedeno da je urednik čitavoga izdanja Vinko
Nikolić, dok se za tehničku opremu zbirke brinuo dr. Dionizije Lasić, OFM. 
pravopisne dogovore između Hrvata i Srba, čitav je svoj kulturni rad u emigraciji posvetio provođenju spomenutih ideja. Okupivši svoje istomišljenike u $\mathrm{Hr}$ vatski ikavski pokret (HIP), započeo je još 1954. godine u Mendozi (Republika Argentina) s izdavanjem nezavisnih novina na kastiljanskome jeziku i esperantu pod nazivom Napredak, kasnije preimenovanim u Napridak - El progreso. Gašenjem Napridka pisanje nastavlja u novome časopisu Svitlenik - El faro, koji od 1968. godine izlazi u glavnome gradu Argentine Buenos Airesu. ${ }^{16}$

Prve radove o važnosti ikavice i korijenskoga pravopisa Petar Tutavac Bilić objavio je još u svibnju 1954. godine te je uputio poziv „svim Hrvatima dobre volje” pozvavši ih na razmišljanje u svojemu članku Par misli o hrvatskom jeziku i pravopisu, koji je objavljen u časopisu Hrvatska 2. rujna 1954. godine. ${ }^{17}$ I autorsku knjigu, koju je naslovio Hrvatski jezik nad ponorom - srbijanštine po emigrantskom tisku i objavio 1963. godine u Napritkovu izdanju, sastavio je po pravilima morfonološkoga pravopisa. Knjiga je zamišljena kao rječnik (ričnik) tako da se u lijevome stupcu nalaze srpske riječi ili ,srbijanštine koje su pisane kako Srbijanski Narod govori - ekavicom", a u desnome stupcu nalaze se hrvatske riječi „kako Hrvatski Narod govori - ikavštinom” (Tutavac 1963: 34).

Vrhunac Tutavčeve borbe za ponovno uvođenje morfonološki koncipirana pravopisa u hrvatski književni jezik bilo je objavljivanje njegova Pravopisa hrvatskoga jezika 1971. godine u Buenos Airesu u nakladi Svitlenika. Na prvim stranicama priručnika, odmah nakon pristupne napomene u kojoj autor obavještava javnost kako tri postojeća digrama ( $l j, n j i d \check{z})$ u hrvatskome književnom jeziku

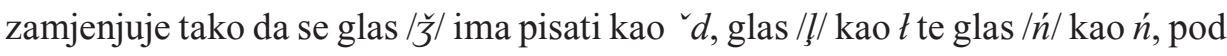
podnaslovom Pravopis Tutavac objašnjava odabir morfonološkoga pravopisnog koncepta. Izrijekom navodi da je u pravopisnome pogledu važna samo jedna značajka hrvatskoga jezika, a to je etimološki ili korijenski način pisanja. Važnost etimološki koncipirana pravopisa po njegovu mišljenju jest čuvanje glavnoga dijela riječi ,prvobitnih suglasnika” (Tutavac 1971: 5) ili porijekla pojedine riječi. Riječi se moraju pisati, po Tutavčevu mišljenju, isključivo po svojemu postanku ili kao izvedenice iz svojega izvornika uvijek pazeći na „srž i čistoću jezika jer se tako čuva njegov pravilan razvitak, posebnost i trajnost" (Tutavac 1971: 5). Nigdje izrijekom u tekstu Tutavac ne spominje drugu i u jezikoslovnoj

16 Više o Petru Tutavcu Biliću vidi u Šunjić 2017: 97-107.

17 Navedeno godište časopisa Hrvatska nije moguće pregledati u NSK-u jer je građa jako oštećena. 
kroatistici u to vrijeme već uvelike prihvaćenu fonološku koncepciju sastavljanja ortografskih priručnika. Ipak, pojašnjavajući u bilješci etimologiju kao granu lingvistike koja „razvstava riči u dilove i traži srž u njima” (Tutavac 1971: 5), nazvavši je u svojoj ikavskoj terminologiji ,pravoričje”, Tutavac spominje i fonetiku, misleći pritom na fonološki način sastavljanja pravopisa. Po njegovu mišljenju to je ,primitivan način pisanja” jer preobličuje riječi, pa tako od slador imamo slatko, od otac-oci, redak - reci, što za Tutavca nikako nije prihvatljivo. Pravopis hrvatskoga jezika Petra Tutavca Bilića sastavljen je od četiriju dijelova (1. Pravopisna pravila, 2. Tehnika pisanja, 3. O pritvorbi glasova, 4. O pisanju tuđih riči) bez pravopisnoga rječnika, koji je, kako navodi autor u bilješci, trebao biti peti dio ovoga priručnika, ali zbog tehničkih razloga nije izrađen pa ga najavljuje u posebnoj knjizi iste veličine u što skorijemu vremenu.

Tutavčev je ortografski priručnik tiskan svega nekoliko tjedana prije izlaska $\mathrm{Hr}$ vatskoga pravopisa Stjepana Babića, Božidara Finke i Milana Moguša koji je objavljen 1972. godine u Londonu u izdanju Nove Hrvatske. ${ }^{18}$ Neki proučavatelji povijesti hrvatskoga jezika ${ }^{19}$ smatraju da je baš objava londonca potisnula Tutavčev pravopis u drugi plan čak i u iseljeništvu. Dva pravopisa s hrvatskim imenom u naslovu utemeljena na različitim pravopisnim koncepcijama i tradicijama, jedan po fonološkom, a drugi po morfonološkom principu, u kratkome vremenskom razmaku doveli su do suvišnosti Tutavčeva djela. Treba reći da nije samo vrijeme objavljivanja presudno utjecalo na neprihvaćanje spomenutoga priručnika u javnosti. Odabir morfonološkoga pravopisnog koncepta, ali i ikavskoga refleksa jata kao jezične osnovice kada je domovinska jezikoslovna kroatistika već njegovala fonološku pravopisnu praksu i ijekavsku osnovicu standardnoga jezika bili su svakako smjeli Tutavčevi pokušaji promjene kontinuiteta razvoja hrvatskoga književnog jezika. Uz dozu nestručnosti i dosta znanstveno upitnih činjenica Tutavčev pravopis ostaje samo zakasnjeli i neostvariv pokušaj promjene standardnojezične i ortografske prakse u hrvatskome književnom jeziku druge polovice dvadesetoga stoljeća.

Tutavčevi suurednici u časopisu Svitlenik Zvonimir Fržop i Ante Gazzari u svojim su radovima, baš kao i on, zdušno zagovarali uvođenje „milozvučnoga na-

\footnotetext{
18 Više o Hrvatskom pravopisu (1972.) te o okolnostima u kojima je objavljen i sudjelovanju hrvatske emigracije u njegovoj objavi vidi u Šunjić 2017: 79-88.

19 Usporedi Vidović 2014.
} 
šega i” (Fržop 1974: 33) kao osnovice hrvatskoga književnog jezika te konačno rješenje svih pravopisnih dilema u hrvatskome književnom jeziku uvođenjem morfonološkoga pravopisa. Tako Gazzari smatra kako bi se ponovnim uvođenjem etimološkoga/korijenskoga pravopisa koji ,čuva glavni dio riči - čuva korin - kao i vezu s drugim ričima, a to znači povist riči” (Gazzari 1969: 110) zauvijek otklonila pravopisna dvojnost u jezikoslovnoj kroatistici. Nadalje ističe da etimologija nekoga jezika nije pitanje naprednosti ili zaostajanja, već je pitanje „čistoće i čuvanja izvornoga jezika” (Gazzari 1969: 109), ona se oblikuje u duhu jezika, odnosno ona je njegov odraz. Svjestan je kako korinsko pisanje nije najbolji izraz za etimologiju jer je ona oznaka za dvoje, morfonološki način pisanja, ali i povijest svake pojedine riječi. Gazzari smatra da nije trebalo dati prednost isključivo fonološkomu konceptu hrvatskoga pravopisa kada se o tome odlučivalo početkom dvadesetoga stoljeća jer se zna da su i hrvatski preporoditelji, kao i književnici prije njih, upotrebljavali morfonološki pravopis. Ako u hrvatskoj književnoj povijesti nije bilo ni jednoga starijeg pisca koji se u potpunosti koristio samo morfonološkim ili samo fonološkim pravopisom, Gazzari se pita zašto fonološki koncipiran pravopis preuzima primat kada se zna „da je u tom brušenju i dotjerivanju hrvatskih jezičnih oblika i pravopisa privladao korinski način pisanja, mnogo prije Rudolfa Hercega i N.D.H.?” (Gazzari 1969: 110). Opisujući povijest hrvatske pravopisne tradicije, autor članka zaključuje kako je Hrvatima Brozov fonetički pravopis nametnut uz pomoć vlasti koja se „odlučila ugoditi Srbima mađaronima sastavivši odbor od pristaša bečkoga književnog dogovora i jedinstvenog hrvatsko-srpskog jezika" (Gazzari 1969: 113) dokinuvši dotadašnji etimološki pravopis za koji se zalagala zagrebačka filološka škola. Tim je člankom Ante Gazzari podržao pobornike uvođenja morfonološkoga koncepta pravopisa posebno napominjući kako spomenuta pravopisna praksa nije proizvod Ureda za hrvatski jezik iz vremena Nezavisne Države Hrvatske, već da je riječ o hrvatskoj pravopisnoj tradiciji koju je Hrvatima nesklona vlast s kraja 19. stoljeća radi nekih nejezičnih interesa jednostavno i naglo promijenila.

Jedna je činjenica kod svih zagovaratelja uvođenja etimološkoga/korijenskoga pravopisa u hrvatski književni jezik u drugoj polovici dvadesetoga stoljeća bila presudna. Nju je možda najjasnije izrekao Mirko Meheš u svojemu članku Hrvatsko pravopisanje i tuđinski nameti (Svitlenik 15/7-8: 16-174), u kojemu je ustvrdio kako „mi, dakle, iztičemo, želimo i tražimo nešto vidljivo što nas udaljuje od Beograda". U jednoj je rečenici tako Meheš izrekao punu istinu o 
dugogodišnjoj borbi i naporu predstavnika hrvatske poratne emigracije koji su pokušali hrvatskoj fonološko-morfonološkoj normi prihvaćenoj u domovini suprotstaviti jedan izrazitiji morfonološki pravopis, a sve u svrhu stvaranja razlike između hrvatskoga i srpskoga književnog jezika.

\section{Zagovaratelji fonološko-morfonološke pravopisne prakse}

U istraženim izvorima za ovaj rad uz već spomenute zagovaratelje ponovnoga uvođenja tzv. korienskoga pravopisa među predstavnicima hrvatske poratne emigracije postojala je i velika skupina onih koji su čvrsto branili dugogodišnju hrvatsku pravopisnu tradiciju fonološkoga tipa započetu još Brozovim Hrvatskim pravopisom iz 1892. godine. Prednjačili su hrvatski kroatisti izvan Hrvatske poput Krste Spalatina, Branka Franolića i Vinka Grubišića, urednika Hrvatske revije Vinka Nikolića, Jakše Kušana i njegove Nove Hrvatske, ali i mnogi drugi hrvatski kulturni i javni radnici u različitim zemljama širom svijeta. Njihovo zajedničko promišljanje bilo je usklađeno sa stajalištem domovinske jezikoslovne kroatistike o važnosti zadržavanja i daljnjega usavršavanja već ukorijenjene fonološko-morfonološke pravopisne norme u hrvatskome književnom jeziku. Oštro su se suprotstavljali bilo kakvim pokušajima promjene hrvatske pravopisne prakse druge polovice dvadesetoga stoljeća, gdje je svaka promjena pravopisnoga koncepta služila samo razlikovanju hrvatskoga od srpskoga književnog jezika tijekom izražene jezične unitarizacije. Da je Broz-Boranićeva pravopisna praksa prve polovice dvadesetoga stoljeća prihvaćena među hrvatskim kroatistima izvan Hrvatske kao jedini mogući pravac u daljnjemu ortografskom razvoju hrvatskoga književnog jezika, vidljivo je iz njihovih stručnih radova i razmišljanja koja su nastajala u drugoj polovici dvadesetoga stoljeća.

Jedan od prvih hrvatskih kroatista izvan Hrvatske koji je jasno i nedvosmisleno govorio o važnosti odabira fonološko-morfonološke ${ }^{20}$ pravopisne norme kao temeljne i jedine u izgradnji hrvatskoga književnog jezika bio je Krsto Spalatin. Već 1955. godine Spalatin u Hrvatskoj reviji pišući nekrolog dr. Dragutinu

\footnotetext{
20 U bilješci broj sedam Spalatin obavještava čitatelje o promjenama u hrvatskoj pravopisnoj terminologiji. Dosadašnji nazivi fonetski mijenja se u fonološki, dok etimološki prelazi u morfonološki (Spalatin 1978). Objašnjenje potkrepljuje ulomkom iz članka Stjepana Babića (članka objavljena u Jeziku 1977., 24, br. 74).
} 
Boraniću, autoru Hrvatskoga pravopisa ${ }^{21}$ dodjeljuje titulu „tvorca hrvatskoga jedinstva”. Jedinstvo Hrvata Boranić je, po Spalatinovu mišljenju, ostvario svojim Boranićevim pravopisom, po kojemu punih pedeset godina „golema većina Hrvata piše istim jedinstvenim pravopisom kao Talijani, Španjolci i Nijemci ali sa stajališta fonetskoga pravopisa dotjeranijim pravopisom nego li su to pravopisi spomenutih naroda” (Spalatin 1955b: 582). Važnost i „srastanje” Hrvata s Boranićevim pravopisom za Spalatina je takvo „da smo bili neugodno iznenađeni, kada je za N.D.H. Hrvatski državni ured za jezik izdao svoje Koriensko pisanje koje su mnogi pozdravili kao novi pravopis različit od srpskoga, ali su se ti isti ljudi našli na sto muka kad su morali pisati korienski" (Spalatin 1955b: 582). O izrazitome morfonološkom pravopisnom konceptu koji je ozakonjen u vremenu Nezavisne Države Hrvatske na drugome mjestu Spalatin piše sljedeće: „budući da je potjecao iz ogorčenosti prema neposrednoj prošlosti, osim u školama i službenim ustanovama, nije se uvažavao"22 (Spalatin 1961: 13). Boraniću Spalatin pripisuje i zaslugu „označavanja polazne točke za budući hrvatski etimološki pravopis” jer „kada je 1930. godine bio zabačen od Beograda u korist Belića, Boranić nije pretvorio hrvatsko past će u srpsko pasće ili bit će u biće, ni londonski Times u Tajmz ili francuski Hugo u Igo" (Spalatin 1955b: 582). Zaključujući svoj nekrolog o hrvatskome pravopiscu, Spalatin posebno ističe važnost vjernosti Hrvata konceptu Boranićeva fonetskoga pravopisa bez mogućnosti povratka u etimološku zbrku, ali samo da bi se imalo različit pravopisni koncept od srpskoga, pa svoj rad zaključuje pitanjem: „Hoćemo li se sada kao Marko iz inata poturčiti?" (Spalatin 1955b: 582).

Očigledno je kako Spalatin u svojim jezikoslovnim radovima razmišlja kao i velika većina domovinskih kroatista toga vremena. Tako u članku o Belićevu pravopisu iz 1953. godine (Spalatin 1955a) donoseći ulomke iz članka Stjepana Ivšića objavljena u časopisu Jezik (br. 2, 1953. godine, str. 38-43) napominje kako mu je profesor Ivšić i za vrijeme Nezavisne Države Hrvatske znao reći da ne prihvaća „Pavelićevu neprirodnu jezičnu agresiju kao ni posrbljivanje hrvatskoga jezika." (Spalatin 1955a: 166) misleći pritom na uvođenje korienskoga pisanja, ali i na pokušaje unificiranja Boranićeva pravopisa Pravopisnim uputstvom iz 1929. godine za vrijeme Aleksandrova apsolutizma. U istome članku

\footnotetext{
21 Više o Boranićevim pravopisima i važnosti svakoga od ukupno deset izdanja vidi u Šunjić 2017: 48-57.

22 „,coming from an exasperated reaction against the immediate past was not heeded except in schools and official institutions“" (Spalatin 1961: 13).
} 
Spalatin zaključuje da je domovinska jezikoslovna kroatistika konačno šezdesetih godina dvadesetoga stoljeća, uz dvije neprihvaćene reforme - Belićevu (1930. - 1940.) te Pavelićevu (1942. - 1945.), „definitivno usvojila Vukov fonetski pravopis" (Spalatin 1955a: 161). Hrvati su slijedili Broz-Boranićevu, a Srbi Belićevu pravopisnu praksu izgrađenu na Vukovim principima uz jednu važnu iznimku: „obično su energično odbacivali ono što su smatrali srpskim jezičnim imperijalizmom"23 (Spalatin 1961: 19).

U turbulentnome poslijenovosadskom vremenu izražene jezične unifikacije hrvatskoga i srpskoga književnog jezika te pokušaja iznalaženja „kompromisnoga ortografskog rješenja" novim zajedničkim Pravopisom srpskohrvatskoga književnog jezika 1960. godine Spalatin čvrsto vjeruje da Broz-Boranićeva pravopisna norma nema alternative u hrvatskome književnom jeziku. Opisujući poglavlje Asimilacija i gubljenje suglasnika u novome zajedničkom pravopisu iz 1960. godine Spalatin napominje kako je pravopisna komisija izabrala jedan srednji put između fonološkoga i morfonološkoga koncepta. Dok su se Hrvati po BrozBoranićevoj pravopisnoj praksi držali ,umjerene fonetike”, Aleksandar Belić odlazi „u fonetici još dalje” (Spalatin 1963: 42). Novi je zajednički ortografski priručnik za Spalatina „,kompromis između hrvatskih fonetičara i Srba, ali kako u Hrvatskoj ima pored fonetičara i etimologičara kompromis između ove dvije struje bolje bi odgovarao hrvatskoj stvarnosti” (Spalatin 1963: 42). ${ }^{24}$ Zaključkom o potrebi kompromisa između dviju pravopisnih koncepcija u hrvatskome književnom jeziku u drugoj polovici dvadesetoga stoljeća Spalatin je još jednom poslao poruku o potrebi prihvaćanja fonološki koncipirana pravopisa kao jedinoga rješenja. Posebno je kritički raspoložen prema svim pokušajima, a najviše ih je bilo u redovima hrvatske poslijeratne emigracije, rehabilitacije nekih prošlih hrvatskih pravopisnih tradicija, poput ponovnoga uvođenja etimološkoga ili izrazito morfonološki koncipiranog tzv. korienskoga pravopisa, smatrajući to jezično neprihvatljivim. Spalatin navodi da početci približavanja hrvatske i srpske fono-

\footnotetext{
23 ,usually rejecting vigorously what they consider Serbian imposition” (Spalatin 1961: 19).

${ }^{24}$ Posebno izdvaja tri rješenja koja je usmeno Krsti Spalatinu u vrijeme korijenskoga pisanja 1943. godine izrekao Stjepan Ivšić o potrebi nadopune Boranićeva pravopisa iz 1940. godine:

„Ne izvršuje se asimilacija po zvučnosti u ovim slučajevima:

1. s prefiksima ob-, nad-, od-, pod-, pred- (obseg, natpis, otpis, potpis, predsjednik);

2. u deklinaciji imenica muškoga roda s nastavkom -ac, -ak (vrabac - vrabca, bezbožac - bezbožca, pregradak - pregradka);

3. ispred inifitivnog -sti (grebsti od grebem)" (Spalatin 1963: 43).
} 
loške pravopisne koncepcije sežu još u devetnaesto stoljeće, u vrijeme izražene ideje o potrebi jedinstva svih južnoslavenskih naroda: „Tijekom 19. stoljeća želja za nacionalnom slobodom i kulturalnim napretkom sve je više rasla. Iz toga su razloga 1814. Srbi položili kamen temeljac za svoj književni jezik, a iz istoga su razloga 1830. Hrvati pojednostavnili svoj etimološki pravopis i odabrali jedan od svojih dijalekata za standardni jezik." ${ }^{25}$ (Spalatin 1961: 9). ${ }^{26}$ Napominje kako je borba između hrvatskih etimologičara i fonetičara trajala punih četrdeset godina, od 1850. do 1892. godine, te da je krajnji ishod borbe bilo ,jezičnopravopisno približavanje Srbima uz sačuvano ime za hrvatski jezik" (Spalatin 1973: 362). Vrijedi napomenuti da Spalatin ortografske priručnike iz vremena Nezavisne Države Hrvatske, sastavljene po pravilima morfonološkoga pisanja, prihvaća kao „dio hrvatskoga pravopisnog života”. Kao jezikoslovni stručnjak prepoznaje fonološko-morfonološki pravopisni koncept kao temelj modernoga ortografskog priručnika hrvatskoga književnog jezika. Prikazujući u Hrvatskoj reviji Babićev, Finkin i Mogušev Hrvatski pravopis, Spalatin nagovještava daljnji razvoj hrvatske pravopisne prakse. Predlaže pronalaženje te usporedbu „slučajeva jednačenja i gubitaka s oblicima nejednačenja (nadpis, ne natpis) i zadržavanja suglasnika (metci, ne meci, kad ionako imamo već muklo $t \mathrm{u}$ vidjet će)" (Spalatin 1973: 367) kako bi se tek onda u okviru hrvatske norme vidjelo gdje će se odstupati od fonetike. Gotovo proročki najavljuje sve veće odstupanje od fonetike u budućemu razvoju hrvatskoga književnog jezika jer ,slovo ostaje slovo a glas se mijenja" (Spalatin 1973: 367) uz najavu potrebe sastavljanja ortoepskoga priručnika hrvatskoga književnog jezika.

Spalatin nije bio pobornik stalne izmjene pravopisnih koncepcija i učestalih tiskanja novih ortografskih priručnika hrvatskoga književnog jezika u svrhu stvaranja razlike između hrvatskoga i srpskoga jezika. Stalne izmjene pravopisnih koncepcija i prelasci s fonetike na etimologiju ili s etimologije na fonetiku po Spalatinovu mišljenju „otešćavaju kontinuitet pokoljenja i time se slabi tradicija, na kojoj se zasniva normalan razvoj svake progresivne civilizacije" (Spalatin 1967: 31). I dok su zagovornici ponovnoga uvođenja izrazitoga morfonološkog

25 „During $19^{\text {th }}$ century the desire for national freedom and cultural progress grew stronger and stronger. For this reason in 1814 the Serbs laid the foundation for their literary language and for the same reason in 1830 the Croatians streamlined their etymological orthography and decided to choose one of their dialects as their standard languages." (Spalatin 1961: 9).

${ }^{26}$ U bilješci sedam Spalatin jasno piše: „Hrvati su 1892. službeno prihvatili fonetski pravopis da budu bliži Srbima." (Spalatin 1969: 29). 
pravopisa među predstavnicima hrvatske poratne emigracije naglašavali kako je to jezikoslovnoj kroatistici potrebno u svrhu razlikovanja hrvatskoga od srpskoga književnog jezika, Spalatin upozorava da hrvatskomu književnom jeziku treba prirodan razvoj uz neke promjene, dok „suparništvo, uskladanje ili diferenciranje sa srpskim stvara nepotrebne komplikacije” (Spalatin 1967: 31).

Spalatinova jezikoslovna promišljanja dijelio je još jedan hrvatski poslijeratni emigrant. U emigrantskome časopisu Naš put nedugo nakon objave Deklaracije o nazivu i položaju hrvatskog književnog jezika člankom $O$ književnom jeziku javio se dr. Ivo Korsky. Oštro se obrušio na sve predstavnike hrvatske poratne emigracije koji pokušavaju ,usred tuđeg jezičnog područja stvoriti novi hrvatski književni jezik, proces suprotan svakom normalnom razvitku” (Korsky 1968: 4). Svojim se istupom Korsky tako svrstao među veliku većinu onih hrvatskih poratnih emigranata koji su zagovarali kontinuitet u razvoju hrvatskoga književnog jezika uz izraženu podršku domovinskoj jezikoslovnoj kroatistici. Kako navodi sam Korsky, dok se u domovini vodi borba za očuvanjem hrvatskoga književnog jezika od tuđih jezičnih konstrukcija, jednaka onoj koja se vodila tijekom devetnaestoga stoljeća u vremenu izražene germanizacije, mađarizacije i talijanizacije, ne smije se dopustiti stvaranje nekakve paralelne emigrantske jezikoslovne kroatistike, već treba čvrsto poduprijeti postojeću domovinsku. Spominje neke pokušaje već iz vremena prve Jugoslavije kada su autohtonci iz Hrvatske seljačke stranke predvođeni Rudolfom Hercegom pokušali bez velika jezikoslovnoga, sociološkoga i povijesnoga znanja uvesti izraziti morfonološki pravopis u hrvatski književni jezik, što je tada predstavljalo veliki „nazadak u pravopisnom razvitku" (Korsky 1968: 4). Vjeruje kako je upravo pod utjecajem Rudolfa Hercega i časopisa Seljačka Sloga, kao ekstremna reakcija na objavljivanje Belićeva pravopisa, a suprotno od mišljenja Matice hrvatske o potrebi prihvaćanja umjerenoga fonološkog pravopisa, u vrijeme Nezavisne Države Hrvatske ta ideja i ozakonjena. To je po njegovu mišljenju dovelo do toga da i među hrvatskim poratnim emigrantima ,skoro nema dva čovjeka koji bi pisali istim pravopisom" (Korsky 1968: 4). Uz zagovaratelje uvođenja izrazite etimologije u hrvatski pravopis posebno se Korsky obrušio i na one predstavnike hrvatske poratne emigracije koji su zagovarali još jedan ekstrem u razvoju hrvatskoga književnog jezika druge polovice dvadesetoga stoljeća. Uvođenje ikavice kao osnovice hrvatskoga književnog jezika u vremenu kada taj isti jezik prolazi kroz dobro utvrđen proces razvitka i standardizacije za Korskoga je samo izazivanje 
zbrke i problema. Kasno je, po njegovu mišljenju, za bilo kakvo mijenjanje jezične osnovice kada se „na ijekavskom izgovoru štokavskoga narječja izgradila i lijepa i znanstvena književnost hrvatskoga naroda, koja je svojom količinom i vrijednošću toliko natkrilila starije pokrajinske književnosti, pa je danas svaki pokušaj vraćanja na predilirsko doba regresivan" (Korsky 1968: 4). Korsky naglašava kako su isto učinili i Srbi odbacivši crkvenoslavenski jezik te na temelju ekavskoga govora štokavskoga narječja „,beogradsko-novosadskog izražajnog oblika" (Korsky 1968: 4) stvorili svoj književni jezik različit od hrvatskoga književnog jezika. Ovo je mišljenje posebno važno istaknuti jer, kako smo već isticali, predstavnici hrvatske poratne emigracije sve su svoje jezične ideje poput uvođenja ikavske osnove ili izrazitoga morfonološkoga pravopisa u hrvatski književni jezik uvijek pravdali kao važan element razlike između hrvatskoga i srpskoga jezika. Za Korskoga taj problem ne postoji jer je uvjeren kako „danas i Hrvati i Srbi potpuno jasno osjećaju, kada se govori ili piše hrvatski ili srpski” (Korsky 1968: 4). U strahu da se uskoro ne pojave neki predlagatelji uvođenja čakavskoga (ekavske ili ikavske osnovice) narječja kao osnove hrvatskoga književnog jezika Korsky poziva hrvatske emigrante da odustanu od ekstremnih jezičnih postupaka poput korijenskoga pravopisa ili ikavske osnove jer novi naraštaji Hrvata u domovini neće moći razumjeti jezik kojim govore i pišu. Smatra kako će novim domovinskim generacijama takav jezik biti „ekscentričan, tuđi i smiješan“ te će se tako ubrzo ,prekinut idejna veza s domovinom koju nije uspjela ni UDBA prekinuti kroz dvadeset godina ni silom ni podvalama” (Korsky 1968: 4). Treba zanemariti, smatra Korsky u svojemu zaključku, te „čistunske” pozive među hrvatskim poratnim emigrantima i nastaviti prirodan i već dobro ucrtan razvoj hrvatskoga književnog jezika uvijek u skladu s domovinskom jezikoslovnom kroatistikom.

I Vinko je Grubišić u nekoliko svojih radova iznosio mišljenja o pravopisnim koncepcijama koja nisu u velikoj mjeri odstupala od spomenutih Spalatinovih i Korskyjevih. Većinu jezikoslovnih radova objavljivao je u Hrvatskoj reviji, koju uz još nekoliko emigrantskih listova poput Nove Hrvatske, Hrvatskog tjednika Danica i dr. možemo svrstati u umjerenije emigrantske publikacije. ${ }^{27}$

Pišući prikaz već spomenutoga Pravopisa hrvatskog jezika Petra Tutavca Bilića, Grubišić oštro reagira na objavu toga priručnika. Posebno se kritički osvrnuo

27 Više u Krašić 2018: 224-246. 
na pisanje infinitivnih oblika bez dočetnoga -i poput izvezat, dovuć, donit, a sve u svrhu potpune ,etimologičnosti”, koju je Tutavac snažno zagovarao. Grubišić pak u takvim oblicima infinitiva vidi nedosljednost, ali i neznanje autora pravopisa o tome kako je hrvatski jezik „umjereno fonetski” i kako su primjeri Zagrepčanin, slatko, gozba i oci već ukorijenjeni u hrvatskoj pravopisnoj normi te da nisu nikakav oblik primitivizma, kako to tvrdi Tutavac (Grubišić 1972). Tutavčev odabir i inzistiranje na izrazito morfonološki koncipiranu pravopisu uz slabo poznavanje nekih jezičnih zakonitosti po Grubišićevu je mišljenju uzrokom mnogih nelogičnosti u samome priručniku. Posebno je to vidljivo na primjerima prelaska $l$ u $o$ kod riječi sa završetkom -lac (bilac, kolac, palac), gdje Tutavac ne prepoznaje da se $l$ nalazi na početku, a ne na kraju sloga ili „etimologičnost širokih rukava" (Grubišić 1972: 305) kada je riječ o stranim imenima i njihovu bilježenju u hrvatskome književnom jeziku (npr. Kamus, Kurie, itd.). Pišući o Hrvatskom pravopisu, koji je objavljen u Londonu u isto vrijeme kada i Tutavčev, Grubišić naglašava kako pretjerano „čistunstvo” (misleći pritom na ponovno oživljavanje nekih pravopisnih rješenja iz vremena Nezavisne Države Hrvatske), ali i zagovaranje pravopisne prakse „širokih rukava” koja se odnosila na pretjerano dopuštanje dvostrukosti u pravopisnim rješenjima, što je bio slučaj zajedničkoga Pravopisa hrvatskosrpskog književnog jezika iz 1960. godine, nepotrebno stvara jezičnu anarhiju koja se postupno normira i pogrešno usmjerava razvoj hrvatskoga književnog jezika. Potvrđujući kako se Brozovim Hrvatskim pravopisom iz 1892. godine zbio ,potpuni zaokret prema fonetičnosti zanemarujući tako stoljetna nastojanja hrvatskih jezikoslovaca" (Grubišić 1973: 21), Grubišić upozorava da je izraziti morfonološki pravopisni koncept ozakonjen u Nezavisnoj Državi Hrvatskoj Korienskim pisanjem „uz mnogo dobrih osobina i vrsno obrađenih poglavlja" (Grubišić 1973: 22) ipak predstavljao nemoguć pravopisni obrat jer nije u obzir uzimao međuratnu pravopisnu praksu u Hrvatskoj. Pretjerano inzistiranje na jednoj prekinutoj pravopisnoj tradiciji i njezino oživljavanje za vrijeme Nezavisne Države Hrvatske bilo je osuđeno na siguran neuspjeh. Na drugome će mjestu Grubišić još jednom istaknuti kako je početkom Drugoga svjetskog rata hrvatski književni jezik „vraćen pedeset godina unatrag" (Grubišić 1987: 434) dvjema političkim odlukama Hrvatskoga državnog ureda za jezik. Izdvojit će tako ponovno „,neumjereno etimologiziranje i pretjerano čistunstvo" (Grubišić 1987: 434) kao dvije radnje u hrvatskome književnom jeziku koje su u velikoj mjeri zaustavile njegov već dobro uhodan 
razvoj. Svojim će se stavovima o važnosti prihvaćanja već ustaljene pravopisne tradicije fonološkoga tipa Grubišić svrstati na stranu jezikoslovaca, kako onih iz emigracije tako i domovinskih, koji su prihvatili Brozov pravopis iz 1892. kao jedan od prvih u nizu pravopisnih priručnika kojima se izgrađivala novija fonološko-morfonološka pravopisna norma u hrvatskome književnom jeziku.

Još je jedan hrvatski kroatist izvan Hrvatske, pišući radove o jezičnim prilikama u drugoj Jugoslaviji, komentirao izmjene pravopisnih praksi u hrvatskome književnom jeziku. Branko je Franolić u knjižici Language policy in Yugoslavia $\left(\right.$ Pariz, 1988.) ${ }^{28}$ naznačio kako su Broz i Boranić na hrvatskoj, a Belić na srbijanskoj strani u svojim ortografskim priručnicima slijedili fonološki koncept Vuka Stefanovića Karadžića, sastavljajući nacionalne pravopise uz jednu bitnu distinkciju, a „njihova se primjena razlikovala u više pogleda” ${ }^{29}$ (Franolić 1988: 9). Gotovo sve promjene pravopisnih koncepcija koje su se u prošlosti događale, ali i cjelokupna jezikoslovna kretanja u kroatistici s kraja devetnaestoga i velikoga dijela dvadesetoga stoljeća, Franolić jasno povezuje s učestalim društveno-političkim mijenama. I pravopisni obrat u vrijeme Nezavisne Države Hrvatske (1941. - 1945.), koji je promijenio dotadašnju gotovo polustoljetnu hrvatsku pravopisnu praksu, za Franolića je samo posljedica nekih nejezičnih okolnosti koje su uvelike utjecale na one jezične: ,pitanje je promjene pravopisnih normi promjenom političkoga režima"30 (Franolić 1988: 12). Usko povezujući jezične s društveno-političkim promjenama, Franolić je još jednom naznačio velik utjecaj politike na jezična pitanja u Jugoslaviji. O istome je utjecaju pisao već spomenuti hrvatski kroatist izvan Hrvatske Krsto Spalatin, koji je za tu potrebu izradio i tablični prikaz podudaranja važnih lingvističkih i političkih događaja u hrvatskoj i srpskoj nacionalnoj i jezičnoj povijesti. ${ }^{31}$ Na kraju valja reći kako je i sam Franolić prepoznao i jasno naznačio još jednu posebnost hrvatske pravopisne tradicije. Dosta puta zagovarane razlike u konceptima hrvatskih pravopisa kroz cijelo dvadeseto stoljeće za mnoge su od tih zagovaratelja imale samo jednu svrhu, a to je „da se što više razlikuje od srpskoga”32 (Franolić 1988: 12). Razlozi koji su dovodili do promjena pravopisnih koncepcija, samo kako bi se hrvatski knji-

\footnotetext{
28 Više u Šunjić 2017.

29 ,their application differed in several respects” (Franolić 1988: 9).

30 „matter of orthographic norms changing with the changing of political regime” (Franolić 1988: 12).

31 Više u Šunjić 2017: 189-190.

32 „to be as distinct as possible from Serbian” (Franolić 1988: 12).
} 
ževni jezik razlikovao od srpskoga, nikada nisu hrvatskomu književnom jeziku donijeli kvalitetan lingvistički razvoj. Najčešće su dovodili do bizarnih situacija u kojima su pravopisni priručnici postajali karikature jer su bili neupotrebljivi, o čemu najbolje svjedoči primjer uvođenja korienskoga pravopisa u Nezavisnoj Državi Hrvatskoj, Zakonskom odredbom o hrvatskom jeziku, o njegovoj čistoći i o pravopisu iz 1941. godine, dok još nisu bila usustavljena pravila morfonološkoga pravopisa.

\section{Zaključno}

Hrvatska je poratna emigracija, iako prostorno odijeljena od domovine, vjerno pratila i pravovremeno reagirala na sva važna događanja u Hrvatskoj. Posebno su bili zaokupljeni pitanjem položaja hrvatskoga književnog jezika u drugoj Jugoslaviji. Događaji i procesi koji su se odvijali na polju jezikoslovne kroatistike nakon završetka Drugoga svjetskog rata pa sve do proglašenja Republike Hrvatske samostalnom i suverenom državom bili su u središtu zanimanja hrvatskih emigranata. Posebno su se istaknuli hrvatski kroatisti izvan Hrvatske koji su, pišući svoje radove o hrvatskome jeziku i objavljujući ih u stranim, ali i vlastitim emigrantskim publikacijama, stvorili jednu paralelnu jezikoslovnu kroatistiku, izrazito blisku onoj domovinskoj. Uz hrvatske kroatiste izvan Hrvatske o položaju hrvatskoga književnog jezika u vremenu izražene jezične unitarizacije u Socijalističkoj Federativnoj Republici Jugoslaviji pisali su i urednici i dopisnici brojnih emigrantskih listova, kulturni radnici, sveučilišni profesori, književnici, ali i političari koji su nakon rata završili u iseljeništvu.

Jedna od bitnih jezikoslovnokroatističkih tema za hrvatske poratne emigrante bila je pitanje odabira pravopisne koncepcije najprihvatljivije hrvatskomu književnom jeziku. U promatranome razdoblju hrvatski poratni emigranti podijelili su se na zagovaratelje dviju pravopisnih koncepcija smatrajući kako je upravo njihovo rješenje najbolje za hrvatski književni jezik. S jedne strane, velika je skupina hrvatskih emigranata, većinom okupljena oko HOP-a, zagovarala povratak izrazito morfonološkomu pravopisnom konceptu još iz vremena zagrebačke filološke škole (tada poznatom kao etimološkom pravopisu), ali i Nezavisne Države Hrvatske, kada je takav koncept (pravo)pisanja bio ozakonjen i potvrđen 
tiskanjem priručnika nazvana Koriensko pisanje. Druga je emigrantska struja branila umjerenu fonološko-morfonološku pravopisnu koncepciju, koju je u to vrijeme uvelike prihvatila domovinska jezikoslovna kroatistika. Gotovo sve zagovaratelje ponovnoga uvođenja izrazite etimologije u hrvatske pravopisne priručnike vodila je samo jedna, po njihovu mišljenju presudna, činjenica da hrvatski književni jezik, a time i njegov pravopis, treba u potpunosti razlikovati od srpskoga. Kada je jugoslavenski (srpski) jezični unitarizam u Socijalističkoj Federativnoj Republici Jugoslaviji prijetio stvaranjem jednoga zajedničkog hrvatskosrpskog književnog jezika, hrvatski su emigranti jedino rješenje vidjeli u isticanju razlika između dvaju jezika. Za neke su razlike bile u pitanjima drugoga pravopisnog koncepta (izrazito morfonološkoga kao hrvatskoga nasuprot dominantno fonološkomu kao srpskomu), dok su neki razliku tražili u promjeni standardnojezične osnovice (uvođenje ikavice). Pobornici umjerenoga fonološko-morfonološkoga koncepta kao jedinoga prihvatljivog u hrvatskoj ortografskoj praksi vjerovali su u tezu koju je zapisao Vinko Nikolić, urednik najpopularnije i najraširenije emigrantske publikacije Hrvatske revije, koji je rekao da vjeruje kako nije važno hoće li se nekada u svojemu jezičnom razvoju hrvatski književni jezik približiti srpskomu jer ta dva jezika, ali i naroda nikada neće postati jedno (Nikolić 1967).

Ovim radom pokušali smo pokazati kako je i među hrvatskim poratnim emigrantima postojala velika skupina onih koji su stručnim i znanstvenim radovima vrednovali razvoj hrvatskoga književnog jezika druge polovice dvadesetoga stoljeća. Vjerovali su kako se samo znanstvenim i jezikoslovno utemeljenim činjenicama, izbjegavajući bilo kakav jezični radikalizam, može i mora nastaviti daljnji razvoj hrvatskoga književnog jezika trudeći se uvijek svoja mišljenja i stavove uskladiti s mišljenjima i stavovima kroatista u domovini. Iako je režim ljudima u Hrvatskoj i Jugoslaviji hrvatsku poratnu emigraciju prikazivao kao sljedbenike Nezavisne Države Hrvatske i promotore ustaške ideologije koji ni nakon rata nisu odustali od političkih, a time i jezičnih programa nastalih za vrijeme Nezavisne Države Hrvatske, ovim radom skrećemo pozornost na postojanje onih hrvatskih poratnih emigranata koji su bili protiv oživljavanja jedne prekinute jezične tradicije. 


\section{Literatura:}

Badurina, Lada. 2017. Pravopisne studije. Matica hrvatska. Zagreb.

BRozović, DALIBOR. 1985. Jezična i pravopisna previranja u Hrvatskoj na prijelazu iz 19. u 20. stoljeće (O jednom razvojnom zaokretu u hrvatskome književnom jeziku). Jezik 33/1. 1-15.

Franolić, Branko. 1988. Language policy in Yugoslavia with special reference to Croatian. Nouvelles éditions latines. Pariz.

FržOP, ZvONIMIR. 1974. Kraljici hrvatske književnosti. Svitlenik 7/5. 33-36.

Gazzari, Ante. 1969. Nešto o korinskom pravopisu. Svitlenik 2/3. 109-114.

Jonke, LuUdevit. 1971. Hrvatski književni jezik 19. i 20. stoljeća. Matica hrvatska. Zagreb.

Kordić, Lucijan. 1964. Exodus. Knjižnica Hrvatske revije. Buenos Aires.

Kordić, LuCIJAN. 1969. Drama i enigma hrvatskoga jezika. O drugoj godišnjici Deklaracije. Hrvatska revija 19/3. 269-271.

Korsky, Ivo. 1968. O književnom jeziku. Naš put 7/67-68. 4.

KraŠIĆ, Wollfy. 2018. Hrvatsko proljeće i hrvatska politička emigracija. Školska knjiga. Zagreb.

Grubišić, Vinko. 1972. Pravopis hrvatskoga jezika. Pero Tutavac. - Naklada Svitlenik, Buenos Aires, 1971. Hrvatska revija 22/2-3. 304-307.

GrubišIĆ, VINKO. 1973. Kao feniks ptica: Hrvatski pravopis. Hrvatska revija 23/1. 1928.

GrubišIć, VinKO. 1987. Vuk S. Karadžić i hrvatski jezik XIX. i XX. stoljeća. Hrvatska revija 37/3. 416-439.

GRUBIŠIĆ, VinKo. 2013. Uspomene na Lucijana Kordića. Osmi neretvanski književni, znanstveni i kulturni susret - Fra Lucijan Kordić, hrvatski književnik, franjevac, svećenik, emigrant. Ur. Šešelj, Stjepan. Neretvanska riznica umjetnina i inih vrijednosti - Hrvatsko slovo. Zagreb - Čitluk. 45-62.

MaČEK, VLADKO. 1960. Hrvatski književni jezik i pravopis. Hrvatska revija 10/4. 416419.

NiKolić, VinKo. Od Baščanske ploče do zagrebačke Deklaracije (1076. - 1967.). Hrvatska revija 17/1-2, 21-25.

SAmardžIJA, Marko. 1993. Hrvatski jezik u Nezavisnoj Državi Hrvatskoj. Hrvatska sveučilišna naklada. Zagreb.

SAMARDŽIJA, MARKo. 2005. Smjernice i stranputice hrvatskoga pravopisa. Jezik na križu / Križ na jeziku. Ur. Hekman, Jelena; Matičević, Ivan. Matica hrvatska. Zagreb. 15-20. 
SAmardžIJA, Marko. 2014. Hrvatski jezik u stoljeću velikih promjena. Vlastita naklada. Zaprešić.

SPAlatin, KRStO. 1955a. Najnoviji Belićev pravopis. Hrvatska revija 5/2. 159-169.

Spalatin, Krsto. 1955b. Nekrolog: U spomen Dr. Dragutina Boranića. Hrvatska revija 5/4. 582 .

Spalatin, Krsto. 1961. First common orthography for Croatians, Serbs and Montenegrins. Journal of Croatian Studies 2. 3-20.

Spalatin, Krsto. 1963. Jedinstveni pravopis hrvatskoga i srpskog književnog jezika. Hrvatska revija 13/1. 36-52.

Spalatin, Krsto. 1967. Borba za hrvatski književni jezik. Hrvatska revija 17/1-2. 2636.

SPALATIN, KRSto. 1969. Rječnik suvremenog hrvatskog i srpskog književnog jezika. $\mathrm{Hr}$ vatska revija 19/1-2. 27-43.

Spalatin, KRsto. 1973. Hrvatski pravopis. Hrvatska revija 23/3. 361-375.

Spalatin, Krsto. 1978. Osnovni hrvatski jezični priručnici. Hrvatska revija 28/1. 3950 .

ŠunJí́, VICE. 2017. Hrvatski jezik kao tema izvandomovinske kulture (1945. - 1990.). Doktorski rad. Filozofski fakultet Sveučilišta u Zagrebu. Zagreb. 216 str.

Vidović, Domagoj. 2014. Jezikoslovno djelovanje Petra Tutavca Bilića. Deveti neretvanski književni, znanstveni i kulturni susret-Petar Tutavac Bilić, hrvatski publicist, književnik, jezikoslovac i prevoditelj. Ur. Šešelj, Stjepan. Neretvanska riznica umjetnina i inih vrijednosti, Hrvatsko slovo. Zagreb. 28-44.

Vince, Zlatko. 1978. Putovima hrvatskoga književnog jezika. Sveučilišna naklada Liber. Zagreb.

Tutavac Bilić, Petar. 1963. Hrvatski jezik nad ponorom - srbijanštine po emigrantskom tisku. Napridkovo izdanje. Buenos Aires.

Tutavac Bilić, Petar. 1971. Pravopis hrvatskoga jezika. Svitlenik. Buenos Aires.

\section{Reflections on the Orthography in Croatian Post-War Emigration}

\section{Abstract}

In the paper, the viewpoints of the representatives of the Croatian post-war emigration in regards to two orthographical concepts, which interchanged in the Croatian orthographical practice, is discussed. Among those who advocated for the return to the morphonological or etymological orthographical concept by writing their linguistic and literary works in accordance with the rules of the morphonological/etymological 
writing, there was also the majority of those who insisted on the usage of orthography predominantly based on the phonological principle. For them, the question of returning to the morphonological (etymological) orthography meant the revival of an interrupted orthographical tradition, which would neglect and devaluate all of the accomplishments in the development of the Croatian literary language in the interwar period.

\section{Considérations divergentes sur l’orthographe étymologique dans l'émigration croate de l'après seconde guerre mondiale}

\section{Abstrait}

Après la Deuxième Guerre mondiale, quelques intellectuels croates émigrés ont proposé d'accepter l'orthographe étymologique de la langue croate. Ainsi par exemple, le politicien Vladko Maček publia un article intitulé „La langue et l'orthographe croates" Hrvatska revija (no 4, X/1960: 416-419) en se servant de l'orthographe étymologique. Dans cet article, il s'opposa vivement contre l'orthographe phonétique utilisée généralement en Croatie et à l'étranger. Parallèlement, le poète croate émigré, Lucijan Kordić publia un livre de poèmes Exodus (1964) en faisant lui aussi usage de l'orthographe étymologique. Petar Tutavac Bilić, écrivain et linguiste croate, qui vivait en Argentine, avait publié une revue culturelle Svitlenik et un livre d'orthographe croate étymologique en dialecte ikavien. Selon lui, l'unique orthographe que tous les Croates devraient employer serait l'orthographe étymologique. Contrairement aux intellectuels en faveur de l'orthographe étymologique, Vinko Nikolić, éditeur de Hrvatska revija ( $L a$ Revue croate) pendant près de quatre décennies, écrivait exclusivement en orthographe phonétique croate. Mentionnons également quelques linguistes croates en émigration, tels Christopher Spalatin et Vinko Grubišić, qui, dans leurs écrits défendirent l'orthographe phonétique en soulignant que l'usage de l'orthographe étymologique fut repris en 1941 pendant l'État indendant croate, ce qui signifiait l'interruption de la longue tradition linguistique croate de l'entre-deux-guerres. Les auteurs de cet article traitent des différentes tendances linguistiques et orthographiques des émigrés croates après la Deuxième Guerre mondiale.

Ključne riječi: korijenski/etimološki pravopis, morfonološki pravopis, fonološki pravopis, hrvatska poratna emigracija, hrvatski kroatisti izvan Hrvatske

Keywords: etymological orthography, morphonological orthography, phonological orthography, Croatian post-war emigration, Croats outside of Croatia

Mots-clés: étymologique, orthographe morphologique, orthographe phonologique, l'émigration croate d'après-guerre, croatistes à l'extérieur de la Croatie. 
Rasprave 46/1 (2020.) str. 407-431 